\title{
UNIVERSITYOF
}

FORWARD

THINKING

WESTMINSTER用

WestminsterResearch

http://www.westminster.ac.uk/westminsterresearch

\section{Animals and the law of armed conflict}

Roscini, M.

This is the peer reviewed version of the following article: Roscini, M. (2017) Animals and the law of armed conflict, Israel Yearbook on Human Rights, 47, pp. 35-67, which has been published in final form at:

https://dx.doi.org/10.1163/9789004341951 004

The WestminsterResearch online digital archive at the University of Westminster aims to make the research output of the University available to a wider audience. Copyright and Moral Rights remain with the authors and/or copyright owners.

Whilst further distribution of specific materials from within this archive is forbidden, you may freely distribute the URL of WestminsterResearch: ((http://westminsterresearch.wmin.ac.uk/)).

In case of abuse or copyright appearing without permission e-mail repository@westminster.ac.uk 


\title{
ANIMALS AND THE LAW OF ARMED CONFLICT
}

\author{
By Marco Roscini*
}

\section{INTRODUCTION}

Animals have played a crucial part in mankind's war efforts since time immemorial. ${ }^{1}$ Hannibal's army famously crossed the Alps in 218 BC riding elephants on its way to Rome. Horses have been used in chariot warfare, cavalry tactics and, after the invention of gunpowder, as draught animals for heavy artillery and cannons. Camel-mounted troops have been employed in desert campaigns, and horses, donkeys, mules and oxen have carried food, water, ammunitions and medical supplies to men at the front. Dogs have proved particularly important in warfare thanks to their heightened sense of smell in locating and detecting hidden explosives and improvised explosive devices and in searching out for wounded soldiers. ${ }^{2}$ Dogs as well as pigeons have also been employed to deliver messages, canaries to detect poisonous gas, and cats to hunt rats in trenches. In recent times, dolphins and sea lions have been used to clear mines, for instance from the Iraqi port of Umm Qasr during the 2003 Operation Iraqi Freedom. ${ }^{3}$ Dolphins and other marine mammals can also carry cameras and hunt for enemy scuba divers. Finally, dogs, cats and other animals have served as pets and military mascots to raise morale and provide comfort to soldiers at the front.

\footnotetext{
* Professor of International Law, University of Westminster. The author would like to thank Professors Yoram Dinstein and Charles Garraway for their comments on a previous version of this article and Dr. Marco Longobardo for his research assistance. All errors and omissions remain the author's sole responsibility. The law is stated as of January 2017 and all websites were last visited on that date.

${ }^{1}$ War memorials to animals have been erected in several cities: the one in London, opened in 2004, is dedicated to those animals who served and died alongside British and Allied forces in wars and campaigns throughout time. The monument has a website: http://www.animalsinwar.org.uk/.

${ }^{2}$ On the use of dogs for military purposes in the United States, see S. D. Cruse, "Military Working Dogs: Classification and Treatment in the U.S. Armed Forces", 21 Animal L. 249 (2014-2015). The US War Dog Program began during the Second World War after the Pearl Harbour attack (ibid. at 254).

3 M. Woods "Flipper goes to war" (27 March 2003) http://www.postgazette.com/healthscience/20030327dolphinscip2.asp. The US Navy has an entire program dedicated to the studying, training and deployment of marine mammals (available at http://www.public.navy.mil/spawar/Pacific/71500/Pages/default.aspx).
} 
The list of possible uses of animals in warfare could continue. What is important to remember, however, is that animals are not only supporting actors in wars between humans, but also victims. Indeed, animals are killed and injured not only when they take part in hostilities, but also as an incidental consequence of attacks on other objectives. ${ }^{4}$ Animals may be negatively affected by hostilities in other ways too. In Africa's Great Lakes region, for instance, elephants are killed and their ivory is smuggled by armed groups involved in non-international armed conflicts to buy weapons and ammunitions. ${ }^{5}$ Animals have also been used in the testing of weapons. ${ }^{6}$

In spite of the above, the law of armed conflict has almost exclusively focused on the protection of human beings. It is not only the black-letter rules that have largely ignored the issue of animals in armed conflict: to the best of this author's knowledge, there is also no international law monograph or article specifically dedicated to this issue, apart from one exception (which contains only limited analysis of the existing rules and mainly focuses on considerations de lege ferenda). ${ }^{7}$ Not even a cursory discussion of the role of animals in war is made in any leading treatise on the law of armed conflict with the exception of Professor Dinstein's book, which briefly refers to them in the context of the definition of "military objective". 8

The present article, then, is the first ever in-depth study of how the law of armed conflict applies to animals and fills a serious gap in the literature. The problem has become of great significance in the light of the public opinion's increasing sensibility towards animal welfare and the emergence of animal rights theories. ${ }^{9}$ Indeed, "the welfare of individual animals (whether wild or domesticated) is emerging as a significant and

\footnotetext{
${ }^{4}$ For example, thousands of sea birds, as well as turtles, sea snakes, fish, shrimps and crabs died as a direct result of the oil spill caused by Iraq at the end of the 1991 conflict in the Persian Gulf (A. Leibler, "Deliberate Wartime Environmental Damage: New Challenges for International Law", 23 Cal. W. Int'l L.J. 67, 127 (1992-1993)).

5 B. Christy, "How Killing Elephants Finances Terror in Africa", National Geographic, Aug 12, 2015, http://www.nationalgeographic.com/tracking-ivory/article.html.

${ }^{6}$ G. L. Francione, “Animals as Property”, 2 Animal L. i, vi (1996).

${ }^{7}$ K. Nowrot, "Animals at War: The Status of 'Animal Soldiers' under International Humanitarian Law", 40 Historical Social Research 128 (2015).

${ }^{8}$ Y. Dinstein, The Conduct of Hostilities under the Law of International Armed Conflict, 106 ( $\left.{ }^{\mathrm{rd}} \mathrm{ed} .2016\right)$.

${ }^{9}$ Animal rights theories go from those who argue that animals only have a limited set of rights to those, like the abolitionists, who argue that no animal is the property of humans and all uses by humans of animals, including food, clothing, amusement or experiments, should be abolished (G. L. Francione, Introduction to Animal Rights: Your Child or the Dog, xxix (2000).
} 
pervasive concern of the international community ...". ${ }^{10}$ From this perspective, it has been observed that " $[\mathrm{t}]$ he jus in bello ... presents itself as a particularly suitable research and reference field for a political theory of animal rights, because in light of current and future technological developments this area of public international law is highly likely and considerably more urgent and accentuated than other legal fields — to be confronted with the practical relevant issue [of] whether to enlarge its scope of applications to actors other than humans and those traditional subjects of law comprising of humans". ${ }^{11}$ As a consequence, "the legal policy fora and discourses on international humanitarian law are, compared to those in other areas of law, currently and in the foreseeable future considerably more receptive towards seriously discussing questions concerning the possible recognition of a legal status for animals". ${ }^{12}$

The main purposes of this article are to assess whether the existing rules of the law of armed conflict provide adequate protection to animals and to highlight the fault lines in the law. The article will distinguish the general provisions of the law of armed conflict, i.e. those that were not adopted with specific regard to animals but the application of which might restrict the killing and injuring of animals, from the provisions that specifically provide protection to animals. To interpret these rules, the article will make use of the rules on interpretation contained in Articles 31-33 of the 1969 Vienna Convention on the Law of Treaties, which generally codify pre-existing customary international law and, therefore, are applicable also to treaties concluded before the entry into force of the Convention. ${ }^{13}$ The analysis will essentially focus on the killing and injuring of animals in the conduct of hostilities, and will only incidentally refer to the exploitation of natural resources, pillage, and seizure of property in occupied territories, because that would be another whole essay. ${ }^{14}$ The article will also not address the question of the applicability of peacetime animal welfare treaties during armed conflict. One point on terminology: although humans are of course also "animals" from a biological

\footnotetext{
${ }^{10}$ M. Bowman, P. Davies \& C. Redgwell, Lyster's International Wildlife Law, 698 (2 $2^{\text {nd }}$ ed., 2010).

${ }^{11}$ See Nowrot, supra note 7, at 133.

${ }^{12}$ Ibid.

131155 U.N.T.S. 331.

${ }^{14}$ The International Criminal Court (ICC), for instance, convicted Germain Katanga for pillage, inter alia, of livestock committed by his militias (Prosecutor v. Katanga, ICC-01/04-01/07, Judgment, 8 March 2014, paras. 949-957). On pillage, seizure and use of property in occupied territories, see Y. Dinstein, The International Law of Belligerent Occupation, 195-209 (2009).
} 
perspective, the present study will employ this expression to refer exclusively to nonhuman species.

\section{GENERAL RULES OF THE LAW OF ARMED CONFLICT WHICH RESTRICT THE KILLING AND THE INJURING OF ANIMALS}

This Section focuses on the general rules of the law of armed conflict, i.e. those that were not adopted with specific regard to animals, and explores if and how they provide effective protection to them in the conduct of hostilities. These rules include: the prohibition of wanton destruction and seizure of enemy property, the principles of distinction and proportionality, the prohibition of superfluous injury and unnecessary suffering, the rules providing special protection to certain objects, and those prohibiting or restricting the use of certain weapons.

\section{A. THE PROHIBITION OF WANTON DESTRUCTION AND SEIZURE OF ANIMALS QUALIFYING AS “ENEMY'S PROPERTY”}

Article 23(g) of the Regulations concerning the Laws and Customs of War on Land annexed to the 1899 Hague Convention II and to the 1907 Hague Convention IV provides that it is prohibited " $\mathrm{t}]$ o destroy or seize the enemy's property, unless such destruction or seizure be imperatively demanded by the necessities of war". ${ }^{15}$ This rule reflects customary international law and now applies in both international and non-international armed conflicts. ${ }^{16}$

Article 23(g) refers to "enemy's property". There is no definition of "property" in the Hague Regulations: do animals qualify as such? This issue has been the subject of debate in animal law scholarship. While welfarist scholars maintain that it is ethically acceptable to continue to see animals as "property" but advocate for a more humane treatment, others (the "abolitionists") argue for the elimination of property status and for making at least

\footnotetext{
15 Text in Documents on the Laws of War, 73 (3rd ed., A. Roberts \& R. Guelf eds., 2000) (hereinafter: Documents on the Laws of War).

${ }^{16}$ J.-M. Henckaerts \& D. Constantin, "Protection of the Natural Environment" in The Oxford Handbook of International Law in Armed Conflict, 470, 472 (A. Clapham \& P. Gaeta eds., 2014). Note that art. 23(g) applies regardless of the amount of damage caused.
} 
some animals legal persons. ${ }^{17}$ Among the former group, David Favre has suggested that a fourth category of property, living property, should be added to the traditional ones (real property, personal property and intellectual property) so to include vertebrate animals. ${ }^{18}$ According to Favre, "some animals, but not all animals, should possess some but not all possible legal rights" and continue to be classified as "property". ${ }^{19}$ These views are challenged by Gary Francione, a leading abolitionist scholar, who argues that "the liberal theory of property assumes that animals have no interests, or, at least, no interests that will prevail against human interests. That is the whole point of classifying animals as "property." Indeed, to classify something as property in the legal sense is to say that the thing is to be regarded solely as a means to the end to be determined by human property owners". ${ }^{20}$ For Francione, then, animals, as sentient beings, should not be classified as property, but as legal persons. If this view is accepted and animals cease to qualify as "property", Article 23(g) would not apply to them. Francione's position, however, does not reflect the lex lata: in the context of the law of armed conflict, in particular, State practice and case-law clearly show that animals are considered in the context of the provisions protecting private and public property. The Eritrea-Ethiopia Claims Commission (EECC), for instance, found "extensive evidence of [the] gratuitous, and patently unlawful, slaughter and burning of the goats, sheep, donkeys and cattle so critical to the survival of rural civilians" and, consequently, found Ethiopia in violation of its obligations under applicable international humanitarian law and "liable to compensate Eritrea for the damage caused by those acts". ${ }^{21}$ In the final award, the Commission also noted that there is not necessarily a clear separation between losses of property and deaths or personal injury, because "[i]n poor countries like Ethiopia and Eritrea, with low incomes and life expectancies, security of property often is vital to survival. Property such as livestock, farmers' tools, utensils and houses has a direct impact on one's possibility

\footnotetext{
17 See D. Favre, "Living Property: A New Status for Animals within the Legal System", 93 Marquette L. R. 1021, 1023 (2009-2010). See also T. L. Bryant, "Similarity or Difference as a Basis for Justice: Must Animals be like Humans to be Legally Protected from Humans?", 70 Law \& Contemp. Probs. 207, 209 (2007); K. Sykes, “'Nations Like Unto Yourselves': An Inquiry into the Status of a General Principle of International Law on Animal Welfare”, 49 Canad. Y.B. Int'l L. 3, 9 (2011).

18 See Favre, supra note 17, at. 1042-1047.

19 Ibid. at 1032.

${ }^{20}$ Gary L. Francione, Animals, Property, and the Law, 46 (2005).

${ }^{21}$ EECC, Partial Award, Western Front, Aerial Bombardment and Related Claims, Eritrea's Claims 1, 3 , 5, 9-13, 14, 21, 25 \& 26, 19 December 2005, paras. 29-30, in 26 R.I.A.A. 291.
} 
to survive. Thus, awards of compensation for loss or destruction of property frequently stem from serious threats to physical integrity", ${ }^{22}$

But do wildlife and stray animals also qualify as "enemy's property"? The ordinary meaning of "property" is "a thing or things belonging to someone". ${ }^{23}$ If "property" is interpreted according to its ordinary meaning, then, it would at best include farm and zoo animals as well as pets, but not wild, stray or unowned animals: as has been noted, "[ $\mathrm{t}]$ hat a living being lives upon or crosses over the real property of a human does not constitute possession of that living being for this purpose. Wild beings within natural ecosystems are not personal property. While governments assert the right to control access to wild animals, they do not have possessory rights or ownership of wild animals". ${ }^{24}$ There are, however, at least two arguments that militate against an interpretation of Article 23(g) limited to domestic animals. The first is that this interpretation is not necessarily consistent with the object and purpose of the provision, which arguably is to protect a belligerent and its nationals against unnecessary economic losses. ${ }^{25}$ Wildlife can be subject to different forms of exploitation, such as hunting and fishing, and its destruction can indeed be an economic loss. Secondly, the US Law of War Manual defines "enemy property" as "[a]ll property located in enemy territory ... regardless of its ownership". ${ }^{26}$ If this definition is correct, Article 23(g) would cover all animals that are present in enemy territory, regardless of whether they are domesticated, wild or stray, privately or State owned. The animals falling outside the scope of Article 23(g) would only be those owned by the belligerent conducting the military operation, or by a neutral State or their nationals (unless such animals are located in enemy territory), and those located in neutral territory

\footnotetext{
22 EECC, Final Award, Ethiopia's Damages Claims, Decision of 17 August 2009, para. 4, in 26 R.I.A.A. 631.

23 The Oxford Compact English Dictionary, 907 (2 $2^{\text {nd }}$ ed., C. Soanes ed., 2003).

${ }^{24}$ Favre, supra note 17, at 1044. See also Leibler, supra note 4, at 105-106.

25 Art. 31(1) of the 1969 Vienna Convention on the Law of Treaties includes, among the main criteria for interpretation, not only the literal one, but also those which take into account a) the context and b) the object and purpose of the provision.

${ }^{26}$ US Department of Defense, Law of War Manual, June 2015 (Updated December 2016), 286.
} 
or beyond the sovereignty of States (unless they are owned by the enemy belligerent or its nationals). ${ }^{27}$

Article 23(g) applies not only to "attacks" as defined in Article 49(1) of Additional Protocol I, but to all seizure, destruction or damage that is the consequence of military operations, such as military movements and manœuvres. If attacks may only be directed against military objectives, ${ }^{28}$ then, the destruction and seizure under Article 23(g) may also occur in relation to property that does not qualify as a military objective, so long as they are justified by imperative military necessity and unless they are limited by other specific regulation. In the Hostage case, the US Military Tribunal clarified that "imperative necessities of war" require that there is "some reasonable connection between the destruction of property and the overcoming of the enemy forces". ${ }^{29}$ The killing of animals by a retreating army to delay the advance of the enemy or the seizure of horses to be used as means of transportation by combatants, then, would be entirely permissible under Article 23(g). ${ }^{30}$ The same cannot be said of the killing and seizure of pets in order to affect the morale of civilians. The rule under examination also does not necessarily prohibit the killing of animals incidental to military operations and movements: as the principle of proportionality only applies to attacks, in the case of other military operations that lead incidentally to the killing of animals the test will be whether or not such incidental destruction is justified by considerations of imperative military necessity. ${ }^{31}$

\footnotetext{
${ }^{27}$ It should also be noted that, under art. 4 of the Hague Regulations and art. 18(1) of Geneva Convention III relative to the Treatment of Prisoners of War, horses may be confiscated from prisoners of war even if they are their personal property.

${ }^{28}$ See below, Section II.B. If the property qualifies as a military objective, the destruction under art. 23(g) is ipso facto justified by imperative necessities of war.

${ }^{29}$ United States v. W. List and others (Hostage case), 8 Trials of War Criminals 34, 66 (1949). As has been observed, the "predicaments lie in determining how direct the advantage that accrues to the military actor has to be, and, if direct enough, how likely the advantage sought is to occur" (M. N. Schmitt, "War and the Environment: Fault Lines in the Prescriptive Landscape", 37 Archiv des Völkerrechts 25, 45 (1999)).

${ }^{30}$ M. Bothe, K. J. Partsch \& W. Solf, New Rules for Victims of Armed Conflicts, 320 (1982). The Nuremberg war crimes tribunals found that even extensive destruction by retreating armies may be justified by the imperative necessities of war under art. $23(\mathrm{~g})$ of the Hague Regulations (The High Command Case (US v. von Lebb), 12 Trials of War Criminals 1, 125 (1949); The Hostage Case, supra note 29, at 69). It should be recalled, however, that art. 57(1) of Additional Protocol I requires that "constant care shall be taken to spare ... civilian objects" in all military operations, not only in attacks (text of the Protocol in 1125 U.N.T.S. 3).

${ }^{31}$ Bothe, Partsch and Solf, supra note 30, at 320; US Law of War Manual, supra note 26, at 288.
} 
The language of Article 23(g) is essentially repeated in Article 53 of the 1949 Geneva Convention IV relative to the Protection of Civilian Persons in Time of War, which prohibits the destruction of property by the Occupying Power in the context of belligerent occupation "except where such destruction is rendered absolutely necessary by military operations". ${ }^{32}$ Unlike Article 23(g) of the Hague Regulations, which applies to the entire territory of the belligerent parties, Article 53 only covers property in occupied territory. ${ }^{33}$ It protects animals that are the "private property of protected persons (owned individually or collectively), State property, that of the public authorities (districts, municipalities, provinces, etc.) or of co-operative organizations". ${ }^{34}$ The considerations with regard to wildlife made above in relation to Article $23(\mathrm{~g})$ can be extended to Article 53. The protection is subordinated to "absolute" military necessity: there does not seem to be a significant difference of meaning between "absolute" and "imperative" necessities of war as used in Article 23(g) of the Hague Regulations and Article 53 of Geneva Convention IV. 35

The wanton destruction of property, including animals, is a grave breach of the Geneva Conventions and a war crime, ${ }^{36}$ but it could also be an element of the crime against humanity of persecution. In the Kupreškić case, the ICTY Trial Chamber found that the Muslim population's livestock, which were killed by military units of the Hrvatsko Vijeće Obrane (HVO) and members of the Jokers during the attack on Ahmici on 16 April 1993, "had for their owners not only economic value, but also and probably even more importantly, emotional, psychological and cultural significance". ${ }^{37}$ The Trial Chamber further noted that the attack "was not a combat operation. Rather, it was a well-planned and well-organized killing of civilian members of an ethnic group, the Muslims, by the military of another ethnic group, the Croats. The primary purpose of the massacre was to

\footnotetext{
3275 U.N.T.S. 287.

33 Commentary, IV Geneva Convention Relative to the Protection of Civilian Persons in Time of War, 301 (J. Pictet ed., 1958). Unlike art. 23(g) of the Hague Regulations, art. 53 only mentions destruction and not also seizure.

${ }^{34}$ Pictet, supra note 33 , at 301.

35 See Dinstein, supra note 14, at 196.

36 See art. 147 of Geneva Convention IV, art. 6(b) of the Charter of the International Military Tribunal at Nuremberg, art. 3(b) of the Statute of the International Criminal Tribunal for the Former Yugoslavia (ICTY), art. 8(2)(a)(iv), art. 8(2)(b)(xiii) and art. 8(2)(e)(xii) of ICC Statute.
}

37 Prosecutor v. Zoran Kupreškić and others, IT-95-16-T, Judgment, Trial Chamber, 14 January 2000, para. 336. 
expel the Muslims from the village, by killing many of them, by burning their houses and their livestock, and by illegally detaining and deporting the survivors to another area. The ultimate goal of these acts was to spread terror among the population so as to deter the members of that particular ethnic group from ever returning to their homes". ${ }^{38}$ The same point is reiterated in Prosecutor v. Dario Kordic and Mario Čerkez: "when the cumulative effect of such property destruction is the removal of civilians from their homes on discriminatory grounds, the "wanton and extensive destruction and/or plundering of ... livestock' may constitute the crime of persecution". ${ }^{39}$

\section{B. THE PRINCIPLE OF DISTINCTION: ANIMALS AS “OBJECTS”}

Article 48 of the 1977 Protocol I Additional to the Geneva Conventions on the Protection of Victims of War provides for the obligation of the belligerent parties to "at all times distinguish between the civilian population and combatants and between civilian objects and military objectives and accordingly [to] direct their operations only against military objectives". Article 52(1) of the Protocol reiterates that "[c]ivilian objects shall not be the object of attack or of reprisals" and Article 52(2) affirms that "[a]ttacks shall be limited strictly to military objectives". This obligation of distinction also applies in non-international armed conflicts, as can be inferred from Common Article 3(1) of the Geneva Conventions, which prohibits "violence to life and person" on those "taking no active part in hostilities", ${ }^{40}$ and more explicitly from Article 13(2) of Additional Protocol II (even though only with regard to civilians and the civilian population, and not civilian objects). ${ }^{41}$

\footnotetext{
${ }^{38}$ Ibid., para. 749.

39 Prosecutor v. Dario Kordić and Mario Čerkez, IT-95-14/2-T, Judgment, Trial Chamber, 26 February 2001, para. 205.

40 A.P.V. Rogers, Law on the Battlefield, 305 (3 ${ }^{\text {rd }}$ ed., 2012).

${ }^{41}$ Rule 10 of the International Committee of the Red Cross (ICRC)'s Study on Customary International Humanitarian Law on the protection of civilian objects against attack, however, applies both to international and non-international armed conflicts (Customary International Humanitarian Law, vol. I, 34 (J.-M. Henckaerts \& L. Doswald-Beck eds., 2005) (hereinafter: ICRC Study)).
} 
The customary status of the principle of distinction is well established. ${ }^{42}$ On 19 December 1969, the UN General Assembly adopted Resolution 2444 by unanimous vote, which expressly recognised the principle of civilian immunity and its corollary requiring the parties to a conflict to distinguish civilians from combatants at all times. ${ }^{43}$ The United States acknowledged that the Resolution is declaratory of customary international law. ${ }^{44}$ The customary nature of the principle of distinction has also been upheld by national and international courts: in particular, according to the 1996 International Court of Justice (ICJ)'s Advisory Opinion on the Legality of the Threat or Use of Nuclear Weapons, the obligation to distinguish between combatants and non-combatants is an "intransgressible [principle] of international customary law" that is "to be observed by all States whether or not they have ratified the conventions that contain" it. ${ }^{45}$ According to the ICTY, "it is now a universally recognized principle ... that deliberate attacks on civilians or civilian objects are absolutely prohibited by international humanitarian law". ${ }^{46}$ The ICTY has also in several cases affirmed that, as far as customary international law is concerned, the prohibition of attacks on civilians and civilian objects applies both in international and non-international armed conflicts. ${ }^{47}$

If attacks, as defined in Article 49(1) of Additional Protocol I, ${ }^{48}$ may only be directed against military objectives, when do animals qualify as such? Animals are not expressly considered in the rules that spell out the principle of distinction. There are, then, three possible interpretive solutions: 1) animals fall under the same classification as humans

42 Ibid. at 3. See also C. Greenwood, "Customary Law Status of the 1977 Additional Protocols" in Humanitarian Law of Armed Conflict - Challenges Ahead, 108 (A. J. M. Delissen \& G. J. Tanja eds., 1991); US Department of Defense, Conduct of the Persian Gulf War: Final Report to Congress (1992), 31 I.L.M. 621-622 (1992).

43 GA Resolution 2444, 19 December 1968. The preamble to this Resolution states that these fundamental humanitarian law principles apply "in all armed conflicts", both international and internal.

44 A. W. Rovine, "Contemporary Practice of the United States Relating to International Law", 67 A.J.I.L. 118,122 (1973).

45 ICJ, Legality of the Threat or Use of Nuclear Weapons, Advisory Opinion, I.C.J. Reports 226 (1996) (hereinafter: Nuclear Weapons), paras. 78-79.

46 Prosecutor v. Kupreškić, supra note 37, para. 521. See also EECC, supra note 21, para. 95.

47 See, e.g. Prosecutor v Tadić, Case No IT-94-1, Decision on the Defence Motion on Jurisdiction, 10 August 1995, para. 127.

${ }^{48}$ Art. 49(1) of the Protocol defines "attacks" as "acts of violence against the adversary, whether in offence or in defence". 
(combatants/civilians) and constitute military objectives when they have combatant status; 2) animals are "objects" (interpreted as a residual notion that includes everything but human beings) and are military objectives when the requirements of Article 52(2) of Additional Protocol I are met; or 3) animals are neither combatants/civilians nor objects, and the law of armed conflict is silent on the conditions under which they may be military objectives. These three alternatives will be explored in turn.

Starting from the first hypothesis, Article 43(2) of Additional Protocol I qualifies the members of the armed forces of a belligerent party as combatants. If " $[\mathrm{t}] \mathrm{he}$ main characteristic of members of the armed forces is that they are trained to engage in combat and fire weapons", ${ }^{49}$ then at least certain animals could qualify as combatants. A legislative proposal submitted to the US Congress, the US Canine Members of the Armed Forces Act, provided, for instance, that military working dogs should not be considered as "equipment" but should be reclassified as canine members of the armed forces. ${ }^{50}$ In some cases, at least unofficially, dogs have been given a military rank and wear a sign distinctive of their rank on their body armour. ${ }^{51}$ It also seems that captured military working dogs could be involved in prisoners of war exchanges between the coalition forces and the Taliban in the conflict in Afghanistan. ${ }^{52}$

The ICRC Commentary of Article 43(2), however, clarifies that "[t]he expression 'armed forces' means 'members of the armed forces', i.e., persons, as explicitly stated in paragraph 2" and that "[i]n itself it ... does not allow, for example, the use of animals trained to attack, who are incapable of distinguishing between an able-bodied enemy and an enemy who is "hors de combat". ${ }^{53}$ Indeed, if they were considered combatants, animals would have not only the rights, but also the obligations associated with this status: the question, therefore, would be "whether or not the average animal combatant can seriously be regarded as being endowed with the capacity to understand and

\footnotetext{
${ }^{49}$ Dinstein, supra note 8, at 41.

${ }^{50}$ H.R. 4103 and S. 2134.

${ }^{51}$ Nowrot, supra note 7, at 132.

${ }^{52} \mathrm{Ibid}$. at $128-129$.

53 Commentary on the Additional Protocols of 8 June 1977 to the Geneva Conventions of 12 August 1949, para. 1672 (Y. Sandoz, C. Zwinarski \& B. Zimmermann eds., 1987) (hereinafter: ICRC Commentary) (emphasis added).
} 
autonomously obey the various legal obligations incumbent upon active participants in armed conflicts under international humanitarian law". ${ }^{54}$

Even admitting, for argument's sake, that certain animals could have combatant status, it would be difficult to qualify the animals not enlisted in the armed forces as civilians: the definition of "civilians" contained in Article 50(1) of Additional Protocol I expressly refers to "persons". It is a significant element of State practice that the above mentioned US Canine Members of the Armed Forces Act was eventually not adopted: military working dogs, therefore, are still qualified as military "equipment" under US legislation and dogs are still not eligible for official military awards. ${ }^{55}$ All in all, if an animal is used by combatants in hostilities, it constitutes a means of warfare, but it is not a combatant itself. $^{56}$

The second option is that animals are considered "objects" for the purposes of the application of the principle of distinction. Article 52(2) of Additional Protocol I, which reflects customary international law, ${ }^{57}$ provides that " $[i] n$ so far as objects are concerned, military objectives are limited to those objects which by their nature, location, purpose or use make an effective contribution to military action and whose total or partial destruction, capture or neutralization, in the circumstances ruling at the time, offers a definite military advantage". 58 "In so far as objects are concerned" has been widely interpreted as implying that there are other categories, in addition to objects, that constitute military objectives and may thus be the target of an attack, in particular combatants, members of organized armed groups in non-international armed conflicts, civilians taking direct part in hostilities, and participants in a levée en masse: the notion of "military objective", in other words, is broader than that of "object". 59 The conditions

\footnotetext{
54 Nowrot, supra note 7 , at 140.

${ }^{55}$ Cruse, supra note 2, at 251-252, 280.

${ }^{56}$ As to veterinary personnel, the US Law of War Manual provides that "veterinary personnel qualify for military medical status, if they are exclusively engaged in providing health services for military personnel (e.g., performing food safety inspections and ensuring that animal illnesses do not spread to humans). However, as a general matter, veterinary personnel would not qualify for military medical status based on being part of the veterinary service" (US Law of War Manual, supra note 26, at 129).

57 See Rule 8 in ICRC Study, vol. I, at 29.

${ }^{58}$ Emphasis added.

59 The ICRC Commentary clarifies that "the definition [contained in art. 52(2)] is limited to objects but it is clear that members of the armed forces are military objectives" (ICRC Commentary, para. 2017). There are, however, also different interpretations that see art. 52(2) as applying to all military objectives, not only objects: the 2013 German Military Manual, for instance, includes the armed forces of a party to the conflict
} 
under which non-objects constitute military objectives, however, are not those spelt out in Article 52(2) of Additional Protocol I. ${ }^{60}$

But are animals "objects" for the purposes of Article 52(2)? It has been suggested, for instance, that animals that contribute to the belligerents' military effort are "matériel" falling under the scope of Article 52(2). ${ }^{61}$ The ordinary meaning of the word "object", however, encompasses only inanimate things. ${ }^{62}$ This conclusion seems to find support in the ICRC Commentary, which defines "objects" as "tangible and visible things" ${ }^{63}$ The travaux préparatoires of Article 52(2) also suggest that the notion of "object" is limited to non-living things. ${ }^{64}$

If we resort to contextual interpretation, however, we will find that Article 54 of Additional Protocol I refers to livestock animals as "objects". Furthermore, the French and Spanish versions of Article 52(2) employ the expressions "biens"/"bienes", which translate into English as "assets", "goods", "possession" or "property". ${ }^{55}$ All these

among the "objects" considered to be military objectives (Federal Ministry of Defence, Law of Armed Conflict Manual, Joint Service Regulation (ZDv) 15/2, May 2013, para. 407).

${ }^{60}$ As has been seen, the targetability of combatants depends on membership of the armed forces (art. 43 of Additional Protocol I). For civilians, it is a consequence of direct participation in hostilities (art. 51(3) of Additional Protocol I), the requirements for which are explored in ICRC, Interpretive Guidance on the Notion of Direct Participation in Hostilities under International Humanitarian Law, 46 (2009) available at http://www.icrc.org/eng/resources/documents/publication/p0990.htm. For participants in a levée en masse, the requirements are provided in art. 4(A)(6) of Geneva Convention III.

61 A. Jahec-Neale, The Concept of Military Objective in International Law and Targeting Practice, 37 (2015).

62 The Oxford Compact English Dictionary defines "object" as "material thing that can be seen and touched" (The Oxford Compact English Dictionary, supra note 23, at 775). The ICRC Commentary quotes the definition contained in the 1970 edition of The Oxford Dictionary: "something placed before the eyes, or presented to the sight or other sense, an individual thing seen, or perceived, or that may be seen or perceived; a material thing" (ICRC Commentary, para. 2007).

${ }^{63}$ ICRC Commentary, para. 2010 (emphasis added).

64 Statement of the US representative, in Official Records of the Diplomatic Conference on the Reaffirmation and Development of International Humanitarian Law Applicable in Armed Conflicts, Geneva, 7 February 1975, CDDH/III/SR.15, vol. XIV, 119, para. 11.

65 Collins-Robert French-English English-French Dictionary, 73 (2 ${ }^{\text {nd }}$ ed., B. T. Atkins et al. eds., 1987); Dahl's Law Dictionary, 46 (5 ${ }^{\text {th }}$ ed., H. Saint Dahl ed., 2010). A bien as a French legal notion is defined as "[t]oute chose matérielle susceptible d'appropriation" (Vocabulaire juridique, 127 (10 ${ }^{\text {th }}$ ed., G. Cornu ed., 2014)), while bienes in Spanish are "[c]osas materiales y derechos sujetos al dominio" (Diccionario de términos jurídicos, 27 (I. Rivera García ed., 1985)). 
expressions have a broader meaning than "object" and are not limited to inanimate things, but also include living beings that are susceptible of appropriation and ownership. The ICRC Commentary is also more ambiguous than it would seem at first sight: the reference to "tangible and visible things" was made to exclude "the general objective (in the sense of aim or purpose) of a military operation", ${ }^{66}$ and not to differentiate between living and inanimate targets.

The third interpretive solution is that animals are considered a third category of military objectives, distinct from human beings and objects. In the third edition of The Conduct of Hostilities under the Law of International Armed Conflict, for instance, Professor Dinstein appears to see "other living creatures" like animals as a separate category of possible awful targets, in addition to objects, combatants and civilians taking direct part in hostilities. ${ }^{67}$ This interpretation, which limits "objects" to inanimate things, is however inconsistent with the object and purpose of Additional Protocol I and of Article 52(2) in particular. The object and purpose of Additional Protocol I is to "improve the protection provided by the [Geneva] Conventions to the victims of international armed conflicts", ${ }^{6}$ and the specific object and purpose of the definition of "military objective" contained in Article 52(2) is to facilitate the application of the principle of distinction in attacks. Under Article 31(1) of the Vienna Convention on the Law of Treaties, between two or more possible interpretations we must choose the one most consonant with this object and purpose. If animals amount to a third category falling outside the scope of Articles 43 and 52(2) of Additional Protocol I, the undesirable normative consequence is that both the criteria to determine whether a certain person is a combatant and therefore targetable and those to establish whether an object is a military objective would be inapplicable to animals. We would be left, therefore, without any valid criterion to establish their targetability. This is clearly an unreasonable interpretive result, which is at odds with the object and purpose of both Additional Protocol I and its Article 52(2) as identified above.

Accordingly, the preferable interpretation appears to be that which considers animals as "objects" under Article 52(2). This ensures that animals are protected under the principle of distinction when they are a civilian object. As Francione has observed,

\footnotetext{
66 ICRC Commentary, para. 2010.

67 In Dinstein's view, the definition of "military objective" contained in art. 52(2) "must be regarded as confined to inanimate objects" (Dinstein, supra note 8, at 105),

68 ICRC Commentary, para. 3685.
} 
"[c]ommon-law and civil-law traditions are dualistic in that there are two primary normative entities in these systems: persons and things. Animals are treated as things, and, more specifically, as the property of persons". ${ }^{69}$ The law of armed conflict, and Additional Protocol I in particular, incorporate this traditional dualistic construction. It is worth noting that "object" is broader than "property": unlike in Article 23(g) of the Hague Regulations, then, no interpretive problem arises under Article 52(2) in relation to wild and stray animals.

If they are indeed considered "objects", animals may be targeted only if they meet the two requirements spelled out in Article 52(2), i.e. when they "by their nature, location, purpose or use make an effective contribution to military action and whose total or partial destruction, capture or neutralization, in the circumstances ruling at the time, offers a definite military advantage". ${ }^{70}$ Horse cavalry, mine-sweeping dolphins and pigeons carrying military communications, for instance, would be military objectives by use and thus targetable. ${ }^{71}$ Many animals are likely to be dual-use objects, for instance pack mules used both by the military to transport weapons and by civilians to carry water. The fact that an object is also used for civilian purposes does not affect its qualification under the principle of distinction: if the two requirements provided in Article 52(2) of Additional Protocol I are present, the object is a military objective but the neutralization of its civilian component needs to be taken into account when assessing the incidental damage on civilians and civilian property under the principle of proportionality. What is prohibited is to attack the dual-use object because of its civilian function or to attack a dual use object where the anticipated military value of the attack is outweighed by the expected civilian damage and/or injury. It should also be recalled that, under Article 52(3) of Additional Protocol I, "[i]n case of doubt whether an object which is normally dedicated to civilian purposes . . . is being used to make an effective contribution to military action,

\footnotetext{
${ }^{69}$ Francione, supra note 6, at ii (emphasis in the original)

70 The two requirements are cumulative: as Boothby notes, "[w]hile in the overwhelming majority of cases, an object which is military in character will also constitute a military objective, the two tests must still be applied because circumstances might arise in which a military object nevertheless does not satisfy the two tests" (W. H. Boothby, The Law of Targeting, 103 (2012)). See also N. Ronzitti, Diritto internazionale dei conflitti armati, 258 (5 $5^{\text {th }}$ ed., 2014).

71 An interesting question is whether certain animals, because of their inherent characteristics, their incorporation in the armed forces or their training, could also be considered military objectives by nature.
} 
it shall be presumed not to be so used". ${ }^{72}$ Unlike its counterpart with regard to persons (Article 50(1) of Additional Protocol I), the customary status of this provision is dubious.

\section{THE PRINCIPLE OF PROPORTIONALITY AND THE PROBLEMS WITH ITS APPLICATION TO ANIMALS}

Another reason to consider animals as "objects" under the current law of armed conflict is that this allows their inclusion in the proportionality calculation of damage incidental to an attack on a military objective. Indeed, Article 51(5)(b) of Additional Protocol I provides that an attack is indiscriminate, and thus prohibited, if it "may be expected to cause incidental loss of civilian life, injury to civilians, damage to civilian objects, or a combination thereof, which would be excessive in relation to the concrete and direct military advantage anticipated". ${ }^{73}$ This provision, commonly referred to as the principle of proportionality, ${ }^{74}$ has been incorporated in several military manuals, including the US Law of War Manual, ${ }^{75}$ the German Military Manual, ${ }^{76}$ the UK Military Manual $^{77}$, and the French Manuel de droit des conflits armés. ${ }^{78}$ It reflects customary international law and, although it does not appear expressly in Additional Protocol II, it is generally accepted that it also applies to attacks in non-international armed conflicts. ${ }^{79}$

\footnotetext{
72 The provision only applies when doubt concerns the use of the object, not its nature, location or purpose (Boothby, supra note 70, at 71).

73 The same language appears in art. 57(2)(a)(iii) and art. 57(2)(b) of Additional Protocol I in relation to the duty to take precautions in attack.

74 The expression is used, for instance, in the British Manual of the Law of Armed Conflict (UK Ministry of Defence, The Joint Service Manual of the Law of Armed Conflict, 68 (2004)).

${ }^{75}$ US Department of Defense, supra note 26, at 241.

${ }^{76}$ Federal Ministry of Defence, Law of Armed Conflict Manual, Joint Service Regulation (ZDv) 15/2, May 2013, Section 512.

${ }^{77}$ UK Manual of the Law of Armed Conflict, supra note 74, at 86.

78 Ministère de la Défense, Manuel de droit des conflits armés, Definition of "Proportionnalité (principe de)", http://www.cicde.defense.gouv.fr/IMG/pdf/20130226_np_cicde_manuel-dca.pdf .

79 See Rule 14 in ICRC Study, vol. I, at 46. See also H.C. 769/02, Public Committee Against Torture in Israel v. Gov't of Israel (2005) (hereinafter: Targeted Killings case), para. 42 (per President Barak), full translation available in 46 I.L.M. 375 (2007).
} 
The fact that harm to animals needs to be factored in when calculating the proportionality of an attack on a military objective finds support in the ICJ's 1996 Advisory Opinion on the Legality of the Threat or Use of Nuclear Weapons, where the Court held that "States must take environmental considerations into account when assessing what is necessary and proportionate in the pursuit of legitimate military objectives. Respect for the environment is one of the elements that go to assessing whether an action is in conformity with the principles of necessity and proportionality" (the natural environment includes the fauna) ${ }^{80}$ Draft Principle 10 of the International Law Commission (ILC)'s Draft Principles on the Protection of the environment in relation to armed conflict, as provisionally adopted in 2015, also provides that "[e]nvironmental considerations shall be taken into account when applying the principle of proportionality and the rules on military necessity". ${ }^{81}$ The same position was taken in the Final Report to the Prosecutor by the Committee Established to Review the NATO Bombing Campaign Against the Federal Republic of Yugoslavia, ${ }^{82}$ and several States have also invoked the applicability of the principle of proportionality to environmental damage. ${ }^{83}$ The fact that the destruction of livestock may be lawful damage incidental to an attack on a military objective is specifically acknowledged by the ICTY Trial Chamber in the Kupreškić case, although the Court found that, in the case before it, the damage was not "collateral", but rather "it was the primary purpose of the attack" ${ }^{84}$

The Final Report by the Committee established to Review the NATO Bombing Campaign Against the Federal Republic of Yugoslavia noted that " $[\mathrm{t}]$ he main problem with the principle of proportionality is not whether or not it exists but what it means and how it is to be applied". ${ }^{55}$ This is because "[t]he intellectual process of balancing the

\footnotetext{
${ }^{80}$ Nuclear Weapons, para. 30.

${ }^{81}$ UN Doc. A/CN.4/L.870/Rev.1, 26 July 2016, at 2.

82 Final Report to the Prosecutor by the Committee Established to Review the NATO Bombing Campaign Against the Federal Republic of Yugoslavia, para. 18 (text in 39 I.L.M. 1257 (2000) (hereinafter: ICTY Final Report)).

${ }^{83}$ See, e.g., Australia (ICRC Study, vol. II, Part 1, at 848-849), Austria (ibid. at 849), Canada (ibid. at 850), Colombia (ibid. at 850), Iran (ibid. at 851), Jordan (ibid. at 851), Romania (ibid. at 852), United States (ibid. at 854,895 ).

${ }^{84}$ Kupreškić, para. 762. See also EECC, supra note 22, at para. 124 ("many animals were lost to starvation, shelling or other causes unrelated to looting. Much property was lost to shelling or other battle damage, for which there is no jus in bello liability").

${ }^{85}$ ICTY Final Report, para 48.
} 
various elements is so complicated, [and] needs to take into account such a huge amount of data and so many factors, that any attempt to design a formula which is both comprehensive and precise would be ridiculous". ${ }^{86}$ These complexities are even more evident when the incidental damage involves animals. Indeed, the value that different military actors will attribute to them will greatly vary: the approach of different societies and individuals to animals is so diverse that any evaluation of proportionality in this context will necessarily be driven by many more variables (of a cultural, economic, religious, ideological, philosophical, educational nature) than in its application to human beings and inanimate objects. As a consequence, belligerents will likely "arrive at disparate conclusions as to the normative boundaries within which [they] must operate". ${ }^{87}$ Those following a utilitarian approach will value animals taking into account only their relevance for human well-being and will only include their usefulness to humans in the proportionality calculation (for example, the killing of animals will be considered relevant because and when it deprives the civilian population of food). The opposite approach will consider the animals' intrinsic value, regardless of their relation to humans. ${ }^{88}$ Between these two extremes, there can be intermediate positions where the utilitarian and the intrinsic value approaches are reconciled in different ways, giving prevalence to the one or the other depending on the circumstances of the case or the type of animal concerned. ${ }^{89}$

Whatever the preferred approach may be, it should be recalled that the principle of proportionality allows even extensive damage to animals if the concrete and direct military advantage anticipated from the attack justifies it. Reverberating and long-term effects on animals arising from an attack on a military objective must be considered when calculating proportionality to the extent that they can be reasonably expected. ${ }^{90}$

\footnotetext{
${ }^{86}$ S. Oeter, "Methods and Means of Combat" in The Handbook of International Humanitarian Law, 115, 191 (3 ${ }^{\text {rd }}$ ed., D. Fleck ed., 2013).

${ }^{87}$ Schmitt, supra note 29 , at 51.

${ }^{88}$ Michael Schmitt has identified these approaches in relation to the application of the principle of proportionality to the environment in general (Schmitt, supra note 29, at 52).

${ }^{89} \mathrm{Ibid}$. at $52-53$.

${ }^{90}$ Boothby, supra note 70, at 105.
} 


\section{THE PROHIBITION OF SUPERFLUOUS INJURY AND UNNECESSARY SUFFERING: DOES IT APPLY TO ANIMALS?}

A cardinal principle of the law of armed conflict is the prohibition of means and methods of warfare causing superfluous injury or unnecessary suffering. ${ }^{91}$ The prohibition first appeared in the Preamble of the 1868 St. Petersburg Declaration and is contained, with slight language differences, in Article 23(e) of the Hague Regulations of 1899 and 1907 and Article 35(2) of Additional Protocol I. ${ }^{92}$ It reflects customary international law applicable to both international and non-international armed conflicts. ${ }^{93}$

The fact that the suffering caused by a weapon is extensive is not sufficient to outlaw it: the suffering must be "unnecessary", i.e. causing "a harm greater than that unavoidable to achieve legitimate military objectives". ${ }^{94}$ However, as the ICRC concedes, "views differ on how it can actually be determined that a weapon causes superfluous injury or unnecessary suffering". ${ }^{95}$ While certain opinions require a balance between the military advantage gained from the use of the weapon in question and the suffering caused, ${ }^{96}$ others resort to a comparative approach: "[s]uffering is unnecessary when, in the circumstances, another practicable military means, causing less suffering to the adverse combatants, could have been used to place the adversary hors de combat". ${ }^{97}$ A third approach focuses on the effects of the weapons and the principle of humanity: when the

\footnotetext{
91 Nuclear Weapons, para. 78.

92 Unlike previous provisions, art. 35(2) of Additional Protocol I contains a reference to methods of warfare, in addition to means. Although innovative at the moment of the adoption of the provision, "it is difficult to imagine on what substantive grounds one could plausibly have objected to the prohibition of methods of warfare 'of a nature to cause superfluous injury or unnecessary suffering', now that means of such a nature have been so prohibited for over a century" (F. Kalshoven, "The Diplomatic Conference on Reaffirmation and Development of International Humanitarian Law Applicable in Armed Conflicts, Geneva, 1974 1977" in Reflections on the Law of War: Collected Essays, 181, 251 (F. Kalshoven, 2007)).
}

93 Rule 70 in ICRC Study, vol. I, at 237. The injury and suffering cover not only physical injury but also severe psychological harm (Dinstein, supra note 8, at 74).

94 Nuclear Weapons, para. 78.

95 ICRC Study, vol. I, at 240.

96 See Nuclear Weapons, Separate Opinion of Judge Guillaume, para. 5; ibid., Separate Opinion of Judge Higgins, para. 14; Bothe, Partsch \& Solf, supra note 30, at 195.

${ }^{97}$ R. Kolb \& R. Hyde, An Introduction to the International Law of Armed Conflicts, 155 (2008). See also Dinstein, supra note 8 , at 75-76. 
suffering they cause are "repugnant to the public conscience", the weapon is unlawful "whatever might be the military advantage sought to be achieved." 98 It has also been suggested that factors like whether the weapon renders death inevitable or leads to permanent disabilities must be considered. ${ }^{99}$ Whatever approach is preferred, only exceptionally would a weapon cause "unnecessary" suffering in all circumstances. The ICRC Commentary of Article 35(2) of Additional Protocol I provides some of the "not very numerous" examples. ${ }^{100}$

While the prohibition of superfluous injury and unnecessary suffering is normally interpreted as protecting combatants, the question arises whether it can also be extended to certain means of warfare that are sentient beings, i.e. animals. If the St. Petersburg Declaration expressly mentions "arms which uselessly aggravate the sufferings of disabled men, or render their death inevitable", 101 both Article 23(e) of the Hague Regulations and Article 35(2) of Additional Protocol I refer to means and methods of warfare that cause superfluous injury or unnecessary suffering, without specifying who the protected subject is. ${ }^{102}$ Reading the ICRC Commentary of Article 35(2), however, it becomes clear that the provision was drafted with humans in mind. In particular, the Commentary refers to " $[t]$ he prohibitions on inflicting superfluous injury or unnecessary suffering on combatants and civilians". ${ }^{103}$ As has been seen in Section II.B., animals do not fit well in the dichotomy combatants/civilians.

The fact remains that neither Article 23(e) of the Hague Regulations nor Article 35(2) of Additional Protocol I specify the protected subject. This allows an evolutionary interpretation of the norms under consideration that extends the prohibition of superfluous injury and unnecessary suffering to animals. In the Advisory Opinion on the Legal

\footnotetext{
98 Nuclear Weapons, Dissenting Opinion of Judge Shahabuddeen, at 403.

${ }^{99}$ ICRC Study, vol. I, at 241.

100 The ICRC's examples include explosive bullets and projectiles filled with glass, "dum-dum" bullets, bullets of irregular shape or with a hollowed out nose, poison and poisoned weapons, any substance intended to aggravate a wound, asphyxiating or deleterious gases, bayonets with a serrated edge, lances with barbed heads (ICRC Commentary, para. 1419). See also ICRC Study, vol. I, 243-244.

${ }^{101}$ Emphasis added.

102 The same applies to the Preamble of the 1980 Convention on Prohibitions or Restrictions on the Use of Certain Conventional Weapons Which May be Deemed to be Excessively Injurious or to Have Indiscriminate Effects (text in 1342 U.N.T.S. 137).

103 ICRC Commentary, para. 1434.
} 
Consequences for States of the Continued Presence of South Africa in Namibia (South West Africa) notwithstanding Security Council Resolution 276 (1970), the ICJ found that "an international instrument has to be interpreted and applied within the framework of the entire legal system prevailing at the time of the interpretation". ${ }^{104}$ The concept of evolutionary interpretation, which is also implied in Article 31(3)(b) of the Vienna Convention on the Law of Treaties, ${ }^{105}$ was employed again by the Court in a subsequent judgment, where it held that "where parties have used generic terms in a treaty, the parties necessarily having been aware that the meaning of the terms was likely to evolve over time, and where the treaty has been entered into for a very long period or is "of continuing duration", the parties must be presumed, as a general rule, to have intended those terms to have an evolving meaning". ${ }^{106}$ Indeed, as recalled by the former President of the Israeli Supreme Court, Aharon Barak, "new reality at times requires new interpretation. Rules developed against the background of a reality which has changed must take on a dynamic interpretation which adapts them, in the framework of accepted interpretational rules, to the new reality". ${ }^{107}$ The arguments in favour of evolutionary interpretation apply strongly to the law of armed conflict: the forward-looking character of this law is demonstrated by the inclusion in Additional Protocol I of Article 36 on the study, development, acquisition or adoption of a new weapon, means, or method of warfare, and of the Martens Clause. ${ }^{108}$

As reaffirmed in Article 1(2) of Additional Protocol I, in particular, the Martens Clause provides that "[i]n cases not covered by this Protocol or by other international agreements, civilians and combatants remain under the protection and authority of the principles of international law derived from established custom, from the principles of humanity and

${ }^{104}$ ICJ, Legal Consequences for States of the Continued Presence of South Africa in Namibia (South West Africa) notwithstanding Security Council Resolution 276 (1970), Advisory Opinion, I.C.J. Reports 16 (1971), para. 53.

105 According to art. 31(3)(b) of the Vienna Convention, treaties shall be interpreted taking into account, inter alia, "any subsequent practice in the application of the treaty which establishes the agreement of the parties regarding its interpretation". See R. Bernhardt, "Evolutive Treaty Interpretation, Especially of the European Convention on Human Rights”, 42 German Y.B. Int'l L. 11, 15 (1999).

106 ICJ, Dispute Regarding Navigational and Related Rights (Costa Rica v. Nicaragua), Judgment, I.C.J. Reports 213 (2009), para. 66.

107 Targeted Killings case, para. 28 (per President Barak). Vice President Rivlin also stated that "international law must adapt itself to the era in which we are living" (ibid., para. 2 (per Vice President Rivlin)).

108 The ICJ found that the Martens Clause's "continuing existence and applicability is not to be doubted" (Nuclear Weapons, para. 87). 
from the dictates of public conscience". A 1961 recommendation by the Consultative Assembly of the Council of Europe declared that "the humane treatment of animals is one of the hallmarks of Western civilisation". ${ }^{109}$ The 1958 UN Conference on the Law of the Sea adopted unanimously a resolution requesting States "to prescribe, by all means available to them, those methods for the capture and killing of marine life, especially of whales and seals, which will spare them suffering to the greatest extent possible". ${ }^{110} \mathrm{~A}$ prohibition of the unnecessary suffering of animals also appears, among others, in Article 5 of the 1935 International Convention Concerning the Transit of Animals, Article 5 of the 1950 Convention for the Protection of Birds, Article 6 of the 1976 European Convention for the Protection of Animals Kept for Farming Purposes, Articles 12, 17 and 32 of the 1979 European Convention for the Protection of Animals for Slaughter, Articles 3, 7, 11 and 12 of the 1987 European Convention for the Protection of Pet Animals, Article 3(6) of Annex II to the 1991 Protocol on Environmental Protection to the Antarctic Treaty. While these Conventions do not automatically apply in armed conflict, ${ }^{111}$ they contribute to shaping the "principles of humanity" and the "dictates of public conscience" referred to in the Martens Clause and allow an evolutionary (re)interpretation of a provision - the prohibition of unnecessary suffering - originally conceived only in relation to human beings. Several states have also maintained that the "dictates of public conscience" now include avoiding unnecessary and extensive damage to the natural environment, which includes the fauna, ${ }^{112}$ and have adopted anti-animal cruelty laws, with some countries recognizing animals as sentient beings worth of protection and compassion even in their constitutions: ${ }^{113}$ as has been observed, "the existence of these

109 Consultative Assembly of the Council of Europe, Recommendation 287 (1961).

110 Resolution 5 on the Humane Killing of Marine Life, UN Conference on the Law of the Sea, Official Records, Doc. A/CONF.13/L56 (1958), Vol. II, Annexes, 144.

111 See ILC's Draft Articles on the effects of armed conflicts on treaties, adopted in 2011, in Report of the International Law Commission, Sixty-third session (26 April-3 June and 4 July-12 August 2011), General Assembly Official Records, Sixty-sixth session, Supplement No. 10 (A/66/10), 175-178.

112 See, e.g., Australia (ICRC Study, Vol. II, Part 1, 887) and Canada (ibid., 850). See also M. Bothe, "The Protection of the Environment in Times of Armed Conflict: Legal Rules Uncertainty, Deficiencies and Possible Developments", 34 German Y.B. Int'l L. 54, 56 (1991); P. Sands \& J. Peel, Principles of International Environmental Law, 794-797 (3 ${ }^{\text {rd }}$ ed., 2012).

113 Sykes, supra note 17, at 29-31. The application of anti-cruelty laws does not normally depend on the domestic or wild nature of the animal concerned (Favre, supra note 17, at 1042). The first legislation on cruelty against animals passed by a national legislature was the Act to Prevent the Cruel and Improper Treatment of Cattle (the "Martin Act"), adopted in 1822 by the British Parliament, which established the criminal offence of cruelty to animals (D. Favre \& V. Tsang, "The Development of Anti-Cruelty Laws 
laws clearly reflects the legislatures' acceptance of the proposition that an animal's interest in being free from unnecessary pain and suffering should be recognized as a value within the legal system". ${ }^{114}$ Some authors have suggested that there is now a general principle of law in the sense of Article 38 of the ICJ Statute that contemplates animal welfare and that is "relevant to the interpretation and amplification of norms established by other means". 115

It can be argued, then, that the principle of unnecessary suffering now applies not only to humans, but also to animals. Having said that, it should be kept in mind that the measure of the unnecessary character of suffering is different in animal welfare law and in the law of armed conflict: while the latter balances it against considerations of military necessity, the former refers to situations where the suffering is not required by a legitimate form of animal exploitation.

\section{E. OTHER GENERAL PROVISIONS THAT MIGHT RESULT IN SOME PROTECTION OF ANIMALS}

Some protection for animals also indirectly results from the application of other rules of the law of armed conflict, such as Article 56 of Additional Protocol I and Article 15 of Additional Protocol II (protection of works and installations containing dangerous forces). Animals must also be "respected and protected" when they are exclusively used

During the 1800s", 28 Det. C.L. R. 1, 4 (1993)). In 2002, the German Constitution was amended to include the words und die Tiere ("and the animals") to the provision that requires the State to respect and protect the dignity of humans (K. M. Nattrass, “ “... und die Tiere' Constitutional Protection for Germany's Animals", 10 Animal L. 283 (2004)). Art. 13 of the Treaty on the Functioning of the European Union recognizes animals as "sentient beings" and requires that "[i]n formulating and implementing the Union's agriculture, fisheries, transport, internal market, research and technological development and space policies, the Union and the Member States shall ... pay full regard to the welfare requirements of animals, while respecting the legislative or administrative provisions and customs of the Member States relating in particular to religious rites, cultural traditions and regional heritage" (text in Official Journal of the European Union (OJ C 115/47) of 9 May 2008). See also the Protocol on protection and welfare of animals attached to the 1997 Treaty of Amsterdam amending the Treaty of the European Union, the Treaties establishing the European Communities and certain related acts. While there is no animal welfare law in China, it appears that the situation is changing and certain cruel practices are now banned also in that country (Sykes, supra note 17, at 32).

${ }^{114}$ Favre, supra note 17 , at 1028.

115 Bowman, Davies \& Redgwell, supra note 10, at 680-681. 
as means of medical transportation. ${ }^{116}$ Article $8(\mathrm{~g})$ of Additional Protocol I defines "medical transport" as "any means of transportation, whether military or civilian, permanent or temporary, assigned exclusively to medical transportation and under the control of a competent authority of a Party to the conflict". ${ }^{117}$ The Commentary specifies that "this provision covers 'any' means of transportation: none is excluded, from the oxdrawn cart to the supersonic jet, or any future means of transportation". ${ }^{118}$ The Spanish Military Manual also states that medical means of transportation for the evacuation of the injured and sick include animals used for medical services on mountains. ${ }^{119}$ The protection of animals as a means of medical transport ceases if they are "used to commit, outside their humanitarian duties, acts harmful to the enemy". ${ }^{120}$ Protection is also granted to animals used by civil defence organizations ${ }^{121}$ or to provide humanitarian relief. ${ }^{122}$

Animals considered sacred in certain religions are not specifically protected by the existing rules of the law of armed conflict. Additional Protocols I and II protect places, not objects, of worship (Article 53 of Additional Protocol I and Article 16 of Additional Protocol II). Some indirect protection, however, may derive from Article 27 of Geneva Convention IV, which provides that "[p]rotected persons are entitled, in all circumstances, to respect for ... their religious convictions and practices, and their manners and customs". Article 75(1) of Additional Protocol I also provides that "[e]ach Party shall respect the person, honour, convictions and religious practices of" those falling

\footnotetext{
116 See art. 35 of Geneva Convention I; art. 21 of Geneva Convention IV; art. 21 of Additional Protocol I; art. 11 of Additional Protocol II. These provisions reflect customary international law and also apply in non-international armed conflicts (see Rule 29 of the ICRC Study, vol. I, at 98).

117 Although not included therein, this definition also applies in the context of Additional Protocol II (Y. Dinstein, Non-International Armed Conflicts in International Law, 165 (2014)).

118 ICRC Commentary, para. 384. The Commentary also clarifies that " $[\mathrm{t}]$ he transportation of wounded with able-bodied soldiers or the transportation of medical equipment and armaments is not medical transportation in the sense of the Protocol" (ibid., para. 383).

119 Gobierno español, Orientaciones - El derecho de los conflictos armados (2 ${ }^{\text {nd }}$ ed., 2 November 2011), OR7-004, tomo I, Section 5.5.c.(3).

120 Art. 21 of Geneva Convention I, art. 13(1) and art. 21 of Additional Protocol I, art. 11(2) of Additional Protocol II.

121 Arts. 62 and 67 of Additional Protocol I.

122 Arts. 70 and 71 of Additional Protocol I.
} 
under the protective scope of this provision: ${ }^{123}$ this might prohibit, for instance, the killing of sacred animals in the presence of the individuals who worship them.

Treaties prohibiting or restricting the use of certain weapons can also play a role in ensuring some level of animal protection in armed conflict. Some of these treaties expressly refer to animals. The 1993 Chemical Weapons Convention, for instance, forbids, inter alia, the use of toxic chemicals defined as "any chemical which through its chemical action on life processes can cause death, temporary incapacitation or permanent harm to human or animals". ${ }^{124}$ An express reference to animals is also contained in Article 7(1)(j) of the Protocol II on Prohibitions or Restrictions on the Use of Mines, BoobyTraps and Other Devices, as amended in 1996, which prohibits "in all circumstances to use booby-traps and other devices which are in any way attached to or associated with: ... animals or their carcasses". ${ }^{125}$ Under the Protocol, then, it is prohibited to use animals, either alive or dead, to conceal explosives. Article I of the Final Document of the Sixth Review Conference of the States Parties to the Convention on the Prohibition of the Development, Production and Stockpiling of Bacteriological (Biological) and Toxin Weapons and on their Destruction provides that "the Convention is comprehensive in its scope and that all naturally or artificially created or altered microbial and other biological agents and toxins, as well as their components, regardless of their origin and method of production and whether they affect humans, animals or plants, of types and in quantities that have no justification for prophylactic, protective or other peaceful purposes, are unequivocally covered by Article I" of the Convention and that "experimentation involving open-air release of pathogens or toxins harmful to humans, animals and plants

123 Art. 75 applies to individuals who are in the power of a Party to the conflict, are affected by armed conflict or by occupation, and do not benefit from more favourable treatment under the Geneva Conventions or under Additional Protocol I (ICRC Commentary, para. 3009).

124 Article II(2) (text in 1974 U.N.T.S. 45). The reference to humans and animals was meant to exclude herbicides (Dinstein, supra note 8, at 93). Animals are also explicitly taken into account in Part XI of the Convention ("Investigations in cases of alleged uses of chemical weapons"). See also UN General Assembly Resolution 2603 (XXIV) (A) of 16 December 1969, which "[d]eclares as contrary to the generally recognized rules of international law, as embodied in the Protocol for the Prohibition of the Use on War of Asphyxiating, Poisonous or Other Gases, and of Bacteriological Methods of Warfare ..., the use in international armed conflict of: (a) Any chemical agents of warfare - chemical substances, whether gaseous, liquid or solid — which might be employed because of their direct toxic effects on man, animals or plants ...".

125 Text in 35 I.L.M. 1206 (1996). The Protocol is additional to the 1980 Convention on Prohibitions or Restrictions on the Use of Certain Conventional Weapons Which May be Deemed to be Excessively Injurious or to Have Indiscriminate Effects. 
that have no justification for prophylactic, protective of other peaceful purposes is inconsistent with the undertakings contained in Article I". ${ }^{126}$

\section{RULES SPECIFICALLY PROTECTING ANIMALS IN ARMED CONFLICT}

There are only a handful of rules in the current law of armed conflict that specifically provide protection to animals during the conduct of hostilities. As far as treaty law is concerned, the only provisions are Articles 35(3), 54 and 55 of Additional Protocol I and Article 14 of Additional Protocol II. With the possible exception of Article 35(3), these rules do not protect animals because of their intrinsic value, but because of their importance for human beings.

\section{A. PROTECTION OF LIVESTOCK AS AN OBJECT INDISPENSABLE TO THE SURVIVAL OF THE CIVILIAN POPULATION}

According to Article 54 of Additional Protocol I, "[i]t is prohibited to attack, destroy, remove or render useless objects indispensable to the survival of the civilian population, such as ... livestock ..., for the specific purpose of denying them for their sustenance value to the civilian population or to the adverse Party, whatever the motive, whether in order to starve out civilians, to cause them to move away, or for any other motive". ${ }^{127}$ As it is clear from its formulation, the provision adopts an anthropocentric approach and protects livestock animals like cows, sheep and chickens not per se, but because and when they are indispensable to the survival of the civilian population. The provision's object

\footnotetext{
${ }^{126}$ Sixth Review Conference of the States Parties to the Convention on the Prohibition of the Development, Production and Stockpiling of Bacteriological (Biological) and Toxin Weapons and on their Destruction (Geneva, 20 November -8 December 2006), Final Document, art. I, in 31 U.N. Disarmament Y.B. 333 (2006). Art. I of the Bacteriological Weapons Convention provides that "[e]ach State Party to this Convention undertakes never in any circumstances to develop, produce, stockpile or otherwise acquire or retain: (1) Microbial or other biological agents, or toxins whatever their origin or method of production, of types and in quantities that have no justification for prophylactic, protective or other peaceful purposes; (2) Weapons, equipment or means of delivery designed to use such agents or toxins for hostile purposes or in armed conflict" (1015 U.N.T.S. 163).

${ }^{127}$ Livestock animals indispensable for the survival of the civilian population may also not be the object of reprisals (art. 54(4)). According to the ICRC Commentary, 'the verbs 'attack', 'destroy', 'remove' and 'render useless' are used in order to cover all possibilities, including pollution, by chemical or other agents, of water reservoirs, or destruction of crops by defoliants ..." (ICRC Commentary, para. 2101).
} 
and purpose, then, is not the protection of animals, but the prohibition of starvation of civilians as a method of warfare. ${ }^{128}$

The list of objects contained in Article 54 is not exhaustive: animals other than livestock could also be encompassed. The provision, however, is limited in its protective scope. First, it does not cover all livestock (or other animals), but only those indispensable to the survival of the civilian population: this is necessarily a contextual assessment that depends not on the type of animal, but on the circumstances of each case (for instance, whether food reserves are available). ${ }^{129}$ Secondly, Article 54 only prohibits actions against animals undertaken "for the specific purpose of denying them for their sustenance value to the civilian population or to the adverse Party". ${ }^{130}$ Article 54, then, does not prohibit the killing of livestock for other legitimate purposes. Collateral damage to livestock is also not a violation of Article 54 "as long as the intention was to gain a military advantage by attacking a military objective". ${ }^{131}$ Thirdly, as noted in the ICRC Commentary of this provision, Article 54 only applies to objects "located in the territory held by the Party to the conflict concerned or that of a co-belligerent as well as in enemy territory": 132 "[i]f they come by sea, the fate of such objects depends on the provisions of the laws of war applicable to ships transporting them", in particular the law of naval blockades. ${ }^{133}$ Fourthly, the protection under Article 54 ceases if animals "are used by an adverse Party: (a) as sustenance solely for the members of its armed forces; or (b) if not as sustenance, then in direct support of military action, provided, however, that in no event shall actions against these objects be taken which may be expected to leave the civilian population with such inadequate food or water as to cause its starvation or force

\footnotetext{
${ }^{128}$ ICRC Commentary, para. 2088.

${ }^{129}$ Schmitt, supra note 29 , at 58.

${ }^{130}$ As art. 54 states, however, the motive is irrelevant.

${ }^{131}$ Executive Series ADDP 06.4, Law of Armed Conflict, Australian Defence Doctrine Publication 06.4, 2006, Part I, Section 5.37.
}

132 ICRC Commentary, para. 2113.

133 Ibid., para. 2114. The Commentary notes that "the objects referred to in paragraph 2 do not fall in the category known as 'absolute contraband of war', and that consequently ships of neutral countries which transport foodstuff destined exclusively for the civilian population may do so without risk of seizure or confiscation" (ibid.). However, art. 22 of the 1909 London Declaration concerning the Laws of Naval War lists as absolute contraband of war "[s]addle, draught, and pack animals suitable for use in war" (text in The Law of Naval Warfare: A Collection of Agreements and Documents with Commentaries, 223 (N. Ronzitti ed., 1988)). 
its movement". ${ }^{134}$ Finally, Article 54 does not prohibit the killing of animals by a party to the conflict "in the defence of its national territory against invasion ... within such territory under its own control where required by imperative military necessity". ${ }^{135}$ A belligerent, then, may destroy objects indispensable to the survival of the civilian population, including livestock, in that part of its own territory under its control, although only when this is required by imperative military necessity. ${ }^{136}$

Language similar to that of Article 54 also appears in Article 14 of Additional Protocol II in relation to non-international armed conflicts, although in a much more concise formulation: as a consequence, scorched earth policies are prohibited in an armed conflict not of an international character. ${ }^{137}$ Both Article 54 and Article 14 reflect customary international law. ${ }^{138}$

\section{B. PROTECTION OF ANIMALS AS AN ELEMENT OF THE “NATURAL ENVIRONMENT”}

Article 55(1) of Additional Protocol I provides that "[c]are shall be taken in warfare to protect the natural environment against widespread, long-term and severe damage. This protection includes a prohibition of the use of methods or means of warfare which are intended or may be expected to cause such damage to the natural environment and thereby to prejudice the health or survival of the population". ${ }^{139}$ Article 35(3) of the same Protocol provides that "[i]t is prohibited to employ methods or means of warfare which are intended, or may be expected, to cause widespread, long-term and severe damage to the natural environment". Unlike Article 55(1), Article 35(3) protects the natural

\footnotetext{
${ }^{134}$ Art. 54(3).

135 Art. 54(5).

136 This, however, does not apply to the part of a belligerent's territory that is under enemy control. Also, the Occupying Power cannot conduct a "scorched earth policy" in occupied territory (ICRC Commentary, paras. 2122-2123).

${ }^{137}$ Boothby, supra note 70, at 438.

${ }^{138}$ Henckaerts \& Constantin, supra note 16, at 476. The United States, however, does not recognize Art. 54 as reflecting customary international law, but it accepts its "underlying principle" that starvation of civilians is a prohibited method of warfare (see US Law of War Manual, supra note 26, at 317-318).

139 Art. 55(2) also prohibits reprisals against the natural environment.
} 
environment without specifications, ${ }^{140}$ and does not subordinate its own application to the existence of a prejudice to the health or survival of the population. ${ }^{141}$ The British Manual of the Law of Armed Conflict also notes that "while Article 35 relates to all methods of warfare whether on land, sea, or in the air wherever in the world they are utilized, Article 55 only relates to environmental damage on the territory or in the territorial sea of a state party to the conflict". ${ }^{142}$ Apart from this, however, the two provisions present more similarities than differences and their common core is the prohibition of "warfare which is intended, or may be expected to have widespread, longterm and severe effects on the natural environment". ${ }^{143}$ Note also that neither Article 35(3) nor Article 55(1) contain any reference to military necessity, which therefore does not constitute a limit to their application.

If the inclusion of the environmental articles in Additional Protocol I was historically due to the serious damage to the flora caused during the Vietnam War, ${ }^{144}$ it is uncontroversial that the provisions in question also extend to the fauna. ${ }^{145}$ Articles 35(3) and 55 protect animals not only directly as a component of the "natural environment", but also indirectly by preserving the ecosystem in which they live. The damage must be "intended" or "expected", which also includes damage to the fauna incidental to an attack on a military objective: if the damage is "widespread, long-term and severe", the attack would be unlawful even if the principles of distinction and proportionality are not

140 ICRC Commentary, para. 1462.

141 The fact that the term "population" is not preceded by the usual adjective "civilian" entails that the provision aims to protect the population in general, including combatants (ICRC Commentary, para. 2134).

142 UK Manual of the Law of Armed Conflict, supra note 74, at 76 (footnote omitted).

${ }^{143}$ L. Lijnzaad \& G. J. Tanja, "Protection of the Environment in Times of Armed Conflict: The Iraq-Kuwait War”, 40 Neth. Int'l L. R. 169, 179 (1993).

${ }^{144}$ In particular, the deforestation practices adopted by the United States.

145 The ICRC Commentary specifies that "[t]he concept of the natural environment should be understood in the widest sense to cover the biological environment in which a population is living. It does not consist merely of the objects indispensable to survival mentioned in Article 54 ... but also includes forests and other vegetation ... as well as fauna, flora and other biological or climatic elements" (ICRC Commentary, para. 2126). Animals are also mentioned in para. 1443 of the ICRC Commentary of art. 35(3). The applicability of this provision to the fauna as an element of the natural environment is confirmed in the 1994 ICRC Guidelines for Military Manuals and Instructions on the Protection of the Environment in Times of Armed Conflict (ICRC, Guidelines on the Protection of the Environment in Times of Armed Conflict (1994), paras. 8 and 9). The text of the Guidelines can be read in Documents on the Laws of War, supra note $15,609-614$. 
breached. ${ }^{146}$ If it appears from the travaux préparatoires that "long-term" has to be interpreted as referring to a period of years or decades, there is no indication of what "widespread" or "severe" mean in the context of Protocol I. According to Rogers, "[a]n examination of the various commentaries on Protocol I leads one to infer that 'severe' means prejudicing the continued survival of the civilian population or involving the risk of major health problems and that 'widespread' means more than the standard of several hundred square kilometres considered in connection with the ENMOD Convention". ${ }^{147}$ Only exceptionally, therefore, will the provisions under examination protect animals. It has been argued, for instance, that "the destruction of all members of a species which occupies a limited region may be 'long-term' and 'severe' since it is irreversible" but not necessarily "widespread" "if the range of the species is spatially restricted". ${ }^{148}$ It is also worth recalling that Ethiopia withdrew a claim related to the migration or loss of wild animals that had been included in its Claim 7 for environmental damage before the EECC. ${ }^{149}$

The customary status of the environmental provisions of Additional Protocol I is questionable. The EECC appears to have implicitly regarded them as customary, as it rejected Ethiopia's claims of unlawful damage to environmental resources committed by Eritrea because the destruction fell "below the standard of widespread and long-lasting environmental damage required for liability under international humanitarian law" (the Commission did not hold relevant the fact that Eritrea had not ratified Additional Protocol I). ${ }^{150}$ According to the ICTY Final Report on the NATO bombing campaign against Yugoslavia, Article 55 of Additional Protocol I "may ... reflect current customary law". ${ }^{151}$ The ICJ's view is ambiguous: in its 1996 Advisory Opinion on the Legality of the Threat or Use of Nuclear Weapons, the Court first stated that Articles 35 and 55

\footnotetext{
146 Dinstein, supra note 8 , at 237.

147 Rogers, supra note 40, at 219.

148 Schmitt, supra note 29 , at 43-44.

${ }^{149}$ EECC, supra note 22, para. 274.

150 EECC, Partial Award, Central Front (Ethiopia's Claim 2), 28 April 2004, para. 53, in 26 R.I.A.A. 155. The Commission also notes that "[m]ost of the provisions of Protocol I of 1977 to the Geneva Conventions were expressions of customary international humanitarian law applicable during the conflict. Had either Party asserted that a particular provision of Protocol I should not be considered part of customary international humanitarian law at the relevant time, the Commission would have decided that question, but that did not happen" (ibid., para. 4).
}

${ }^{151}$ ICTY Final Report, para. 15. 
"embody a general obligation to protect the natural environment against widespread, long-term and severe environmental damage", and then conceded that these provisions are "powerful constraints" only for the States having subscribed to them. ${ }^{152}$ Draft Principle 8 of the ILC Draft Principles on the Protection of the environment in relation to armed conflict, as adopted in 2015, contains language softer than that of Additional Protocol I and provides that "[c] are shall be taken to protect the natural environment against widespread, long-term and severe damage". ${ }^{153}$ As to State practice, several States have maintained that the two environmental provisions of Additional Protocol I reflect customary international law ${ }^{154}$ and have included them in their military manuals and national legislations, although the language varies. ${ }^{155}$ On the other hand, France, the United Kingdom and the United States deny that the provisions under examination have achieved customary status. ${ }^{156}$ The United States, in particular, claims that they are "too broad and ambiguous". ${ }^{157}$ In its official response to the publication of the ICRC Study, the United States argued that the Study's conclusions on the customary status of the prohibition of the use of methods or means of warfare that are intended or may be expected to cause widespread, long-term and severe damage to the natural environment are flawed, as they do not accurately assess the practice of specially affected States, they examine "only limited operational practice" which did not reach the required degree of

\footnotetext{
${ }^{152}$ Nuclear Weapons, para. 31. According to Sands and Peel, however, "[ $[$ ]he implication that the 'powerful constraints' of the Protocol did not — at least in 1996 - reflect customary law, may no longer hold true with the adoption of the 1998 Statute of the International Criminal Court and France's accession, on 11 April 2001, to the Protocol" (Sands \& Peel, supra note 112, at 796).
}

${ }^{153}$ UN Doc. A/CN.4/L.870/Rev.1, 26 July 2016, at 2.

${ }^{154}$ ICRC Study, Vol. II, at 887-898.

155 Ibid. at $879-887$.

${ }^{156}$ ICRC Study, vol. I, at 154. According to the Study, however, the practice of the three States is "not totally consistent". Furthermore, "[a]s these three States are not 'specially affected' States as far as the infliction of this type of damage is concerned, this contrary practice is not enough to have prevented the emergence of this customary rule". Being "specially affected States" only in regard to the possession of nuclear weapons, the only consequence of their objection could be that the United Kingdom, the United States and France "are not bound by this specific rule as far as any use of nuclear weapons is concerned" (ibid.).

157 "Remarks of M. J. Matheson, Deputy Legal Adviser, US Department of State, at The Sixth Annual American Red Cross-Washington College of Law Conference on International Humanitarian Law: A Workshop on Customary International Law and the 1977 Protocols Additional to the 1949 Geneva Conventions", 2 Am. U.J. Int'l L. \& Pol'y 419, 424 (1987). 
damage, and they offer no evidence of opinio juris. ${ }^{158}$ In Washington's view, only the destruction of the environment carried out wantonly is prohibited, although "methods and means of attack should be employed with due regard to the protection and preservation of the natural environment". ${ }^{159}$

As to non-international armed conflicts, it is to be noted that a proposal by Australia to include a provision similar to Article 35(3) in Additional Protocol II was rejected. ${ }^{160}$ According to the ICRC Study, customary international law prohibiting major damage to the natural environment in non-international armed conflict might emerge "in due course". ${ }^{161}$ The ICRC Guidelines on the Protection of the Environment in Times of Armed Conflict encourage the parties to a non-international armed conflict "to apply the same rules that provide protection to the environment in international armed conflict" and urge states "to incorporate such rules in their military manuals and instructions on the laws of war in a way that does not discriminate on the basis of how the conflict is characterized". 162

Articles 35(3) and 55 of Additional Protocol I are not the only environmental provisions of the law of armed conflict. Under Article I(1) of the Convention on the Prohibition of Military or Any Other Hostile Use of Environmental Modification Techniques (En-Mod Convention), adopted by the UN General Assembly in 1976 and opened for signature in 1977, the parties agree "not to engage in military or any other hostile use of environmental modification techniques having widespread, long-lasting or severe effects as a means of destruction, damage or injury to any other State Party". ${ }^{163}$

158 "Letter from John Bellinger III, Legal Adviser, U.S. Department of State, and William J. Haynes, General Counsel, U.S. Department of Defense, to Dr. Jakob Kellenberger, President, ICRC, regarding Customary International Law Study (3 November 2006)”, 46 I.L.M. 520 (2007).

159 Joint Doctrine for Targeting, Joint Publication 3-60 (31 January 2013), available at https://www.justsecurity.org/wp-content/uploads/2015/06/Joint_Chiefs-Joint_Targeting_20130131.pdf, Appendix A, at A-7. See also Department of the Navy, The Commander's Handbook on the Law of Naval Operations (July 2007) NWP 1-14M, Section 8.4.

160 ICRC Study, vol. II, part 1, at 877-878.

161 Ibid., vol. I, at 157.

162 ICRC, Guidelines on the Protection of the Environment, supra note 145, para. 6.

1631108 U.N.T.S. 151. Under arts. 35(3) and 55 of Protocol I, the damage to the environment must be widespread, long-term and severe, while in the En-Mod Convention, which replaces "and" with "or", it suffices that only one of the conditions is satisfied. The adjectives used in the En-Mod Convention have a meaning different from that of their counterparts in the Protocol. In particular, "widespread" means "encompassing an area on the scale of several hundred square kilometres", "long-lasting" implies "a period 
The techniques referred to in Article I are defined in Article II as those "for changing through the deliberate manipulation of natural processes - the dynamics, composition or structure of the Earth, including its biota, lithosphere, hydrosphere and atmosphere, or of outer space". ${ }^{164}$ Examples of such techniques are - according to the second understanding submitted by the UN Conference of the Committee on Disarmament to the General Assembly together with the Convention - "earthquakes; tsunamis; an upset in the ecological balance of a region; changes in weather patterns (clouds, precipitation, cyclones of various types, and tornadic storms); changes in climate patterns; changes in ocean currents; changes in the state of the ozone layer; and changes in the state of the ionosphere". ${ }^{165}$ The Final Declaration of the 1992 Second Review Conference of the Parties to the En-Mod Convention declares that the Convention is applicable to the use of herbicides if such use "upsets the ecological balance of a region, thus causing widespread, long-lasting or severe effects as the means of destruction, damage or injury to another State Party". ${ }^{166}$ A use of herbicides aimed at causing the extermination of bees, for instance, could fall under the prohibitive rules of the En-Mod Convention if its purpose is to produce environmental modifications through the loss of all the plants that bees pollinate and of the animals that eat those plants. The manipulation, however, must be "deliberate" and not be the collateral result of an attack on a military objective. ${ }^{167}$ The damage caused by the hostile use of the environmental modification technique must also be inflicted to the territory of another State Party to the En-Mod Convention: damage to areas beyond national jurisdiction, to the territory of a State that has not ratified the Convention and even to the territory of the state using the environmental modification technique is not prohibited. ${ }^{168}$

of months, or approximately a season" (while in Additional Protocol I it refers to years or decades) and "severe" means "involving serious or significant disruption or harm to human life, natural and economic resources or other assets" (Documents on the Laws of War, supra note 15, at 407). The understanding relating to art. 1 makes clear that "the interpretation set forth above is intended exclusively for this Convention and is not intended to prejudice the interpretation of the same or similar terms if used in connection with any other international agreement" (ibid.).

164 Biota includes plant and animal life (Executive Series ADDP 06.4, Law of Armed Conflict, Australian Defence Doctrine Publication 06.4, 2006, Part I, Section 5.50).

165 Documents on the Laws of War, supra note 15, at 408.

166 ICRC Study, vol. II, Part 1, at 1769.

${ }^{167}$ Dinstein, supra note 8, at 233.

168 Ibid. at 234. 
The ICRC Study on Customary International Humanitarian Law ambiguously argues that, although the customary status of the En-Mod Convention is unclear, "there is sufficiently widespread, representative and uniform practice to conclude that the destruction of the natural environment may not be used as a weapon". ${ }^{169}$

\section{CONCLUSIONS AND THE WAY AHEAD}

Greater attention needs to be paid to the protection of animals during armed conflict, an issue that the jus in bello has yet to address in a systematic manner. While the law of peacetime now includes several treaties aimed at protecting animals, ${ }^{170}$ there are only a handful of international humanitarian law rules that specifically address them, and they apply only in exceptional circumstances. Furthermore, with the exceptions of the principle of unnecessary suffering (in the reinterpretation suggested above) and of Article 35(3) of Additional Protocol I, both general and specific provisions adopt an anthropocentric approach and primarily aim to protect the interests of humans, not the welfare of animals. The language used to refer to animals in the law of armed conflict suggests itself that the interests of animals are completely extraneous to the normative framework of the existing rules. Indeed, when it categorizes them as "property" or "objects", the jus in bello objectifies animals even though, unlike inanimate things, they are sentient beings with their own interests, which can take independent actions and are capable of subjective perception and suffering.

What are the possible remedies to these inadequacies? Belligerents may conclude special agreements "at any time" in relation to "all matters concerning which they may deem it suitable to make separate provision". ${ }^{171}$ Customary international law rules

\footnotetext{
${ }^{169}$ ICRC Study, vol. I, at 156.

170 Treaties for the protection of animals are not a new phenomenon. Early examples include the 1900 Convention for the Preservation of Wild Animals, Birds and Fish in Africa and the 1902 Convention to Protect Birds Useful to Agriculture. These early treaties, however, were essentially motivated by human interests and did not aim at protecting animals qua animals. Some of them allowed the destruction of animals when they were prejudicial to human interests (M.J. Bowman, "The Protection of Animals under International Law", 4 Conn. J. Int'l L. 487 (1988-1989)). For a list of more recent conventions, see Sykes, supra note 17, at $22 \mathrm{ff}$., $32 \mathrm{ff}$. The World Organization for Animal Health (OIE) is an international organization with 180 Member States that focuses on the development of animal welfare standards and publishes codes and manuals on animal health and sanitary standards (http://www.oie.int).
}

${ }^{171}$ See art. 6 of Geneva Conventions I, II and III and art. 7 of Geneva Convention IV. 
specifically protecting animals in armed conflict could also eventually sediment, although it has been observed that "compelling evidence for the existence of any customary principle concerning welfare should probably not be expected since state practice regarding the protection of animals is almost invariably attributable to domestic standards and sensibilities rather than to any sense of international legal obligation, rendering proof of opinio juris extremely difficult". ${ }^{172}$

Finally, a new treaty providing for specific rules protecting animals in armed conflict could be adopted, but the drafters would have significant challenges to face at the negotiating table. In particular, they would have to agree on the treaty's normative purpose and on its subjective scope of application, i.e. what categories of animals it should encompass. ${ }^{173}$ Dogs, elephants, camels, dolphins, cats, whales and mammals in general would probably be unchallenged candidates for inclusion. More debatable would be its extension to all vertebrates, not to mention smaller creatures like insects. In any case, it is likely that different species would be assigned different levels of protection.

It was, however, not the purpose of this article to canvass any particular solution to what this author perceives as a fault line in the law of armed conflict. The aim was rather to identify and question the traditional limits of this discipline in relation to animals. We need to abandon our traditional perceptions and move towards a more animal friendly conception of the law of armed conflict. Determining how exactly we can do so - how we can balance human interests with those of animals in war - is another task for another day.

\footnotetext{
172 Bowman, Davies \& Redgwell, supra note 10, at 673 (emphasis in the original).

${ }^{173}$ Nowrot, supra note 7, at 139.
} 